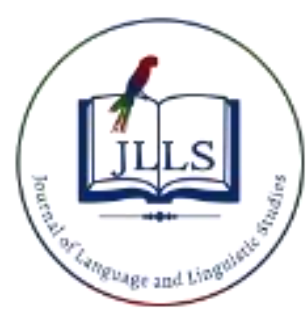

Available online at www.jlls.org

JOURNAL OF LANGUAGE AND LINGUISTIC STUDIES

ISSN: $1305-578 \mathrm{X}$

Journal of Language and Linguistic Studies, 16(2), 565-579; 2020

\title{
Difficulties faced by the undergraduate students in the process writing approach
}

\author{
Nejla Gezmişa1 iD \\ ${ }^{a}$ Kırlkkale University, Kırlkkale, Turkey
}

\section{APA Citation:}

Gezmiş, N. (2020). Difficulties faced by the undergraduate students in the process writing approach. Journal of Language and Linguistic Studies, 16(2), 565-579.

Submission Date: 09/10/2019

Acceptance Date: 25/02/2020

\begin{abstract}
The purpose of this study is to identify in which stage/stages of the Process Writing Approach students have difficulties most. This posttest-experimental study was applied to the 50 first-year students studying English Translation and Interpreting. The students were expected to produce an essay with the help of the Process Writing Approach at the end of the procedure. Their essays were assessed with a checklist prepared by the researcher according to the steps of the approach. At the end of the analysis, it is found that the students have success in the application of the approach in their writing class. Furthermore, it is seen that the students have difficulties in the application of the second stage, drafting, of the approach. The Process Writing Approach is a difficult and timeconsuming approach in writing. It is found in this study that drafting and revising are problematic stages for undergraduate students. Thus, it is thought that it will be better for teachers to warn students to prepare enough before the production stage. Also, having separate lectures on the organization of paragraphs before the application of the approach will be useful for students.
\end{abstract}

(C) 2020 JLLS and the Authors - Published by JLLS.

Keywords: Process Writing Approach; writing

\section{Introduction}

Writing is an inseparable part of a language. Raimes (1983) presents a diagram which demonstrates the points that writers deal with during the writing process. According to this diagram, writers focus on syntax, grammar, context, mechanics (spelling, punctuation, handwriting, etc.), organization, word choice, audience and purpose in order to generate clear, fluent and effective communication ideas (p.6). Therefore, teaching writing is also a process that involves all of these areas of languages.

There are various approaches to teaching writing. These include the controlled-to-free writing approach, the free writing approach, the paragraph-pattern approach, the grammar-syntax-organization approach, and the communicative approach, all of which focus on one separate area of languages. Traditional approaches to teaching writing emphasize a teacher-centered model and the written product itself. The students are usually asked to produce a part of writing in a limited time with the given topic

\footnotetext{
1 Corresponding author. Tel.:

E-mail address: nejlagezmis@ gmail.com
} 
or to write a similar piece of writing after given a sample one. Moreover, their writing is assessed in terms of grammar, punctuation, spelling, and vocabulary. Also, they do not have a chance to change or to make any corrections with their writing as their time is limited in the class. Thus, students' own ideas and expressions or their needs to make amendments to their writing are ignored in the practice of writing.

Recently, there is a paradigm change concerning the development of students' writing ability during the process itself because writing is seen as a combination of several interactive and recursive stages or parts of languages. In this context, PWA (the Process Writing Approach) is commonly preferable in the development of writing skills in teaching language. PWA is an approach to writing, where language learners emphasise on the process by which they generate their written products rather than on the products themselves (Onozawa, 2010, p. 154). In other words, this approach considers writing as a combination of some different actions and it places more emphasis on the stages in which students perform these actions while constructing meaning in their writing. By focusing on the writing process, learners come to understand themselves more and find how to work through the writing. They may explore what strategies conform to their style of learning.

\subsection{Literature review}

It is obvious from the several studies in the literature that PWA successfully helped students develop their writing skills in language teaching (Bayat, 2014; Cheung \& Chan, 1994; Daze \& Ebibi, 2014; Goldstein \& Carr, 1996; Ho, 2006; Jacob \& Talshir, 1998; Mahon \& Yau, 1992; Nabhan, 2016; Olajide, 2013; Schanella, 1982). Namely, students have success in learning writing via this approach. However, it is yet unknown whether students have any difficulties in this approach, thus it needs further investigation. Considering the most difficult stages of the approach, teachers can pay attention to these stages more or they can take some precautions before the application of the approach in the classroom. Thus, the purpose of this study is to identify the stage/stages of PWA in which the students have difficulties most.

Besides, it is thought that gender factor affects student's performance in various disciplines of education. In the first systematic review of the psychological literature on gender differences presented by Maccoby and Jacklin (1974), it is argued that gender differences in verbal ability and language were well established (p. 351). Also, there are a number of studies that have found substantial gender differences in writing and they have concluded that females have better achievement in writing ability than males (Camarata \& Woodcock, 2006; Nowell \& Hedges, 1998; Pajares \& Valiante, 1999; Reilly, Neumann and Andrews, 2019; Reynolds, Scheiber, Hajovsky, Schwartz and Kaufman, 2015; Scheiber, Reynolds, Hajovsky and Kaufman, 2015). For this reason, whether gender factor affects the difficulties in PWA is another item to be searched in this study.

\subsection{Research questions}

With the abovementioned aim, the study seeks to find answers to the following research questions:

1. Do the students have any failures in the application of PWA?

- Is there a difference between the female and male students in terms of the failure in the application of PWA?

2. Do the students have any failures in the application of the first stage of PWA?

- Is there a difference between the female and male students in terms of the failure in the application of the first stage of PWA?

- Is there a difference between the successful and unsuccessful students in terms of the failure in the application of the first stage of PWA? 
3. Do the students have any failures in the application of the second stage of PWA?

- Is there a difference between the female and male students in terms of the failure in the application of the second stage of PWA?

- Is there a difference between the successful and unsuccessful students in terms of the failure in the application of the second stage of PWA?

4. Do the students have any failures in the application of the third stage of PWA?

- Is there a difference between the female and male students in terms of the failure in the application of the third stage of PWA?

- Is there a difference between the successful and unsuccessful students in terms of the failure in the application of the third stage of PWA?

5. Do the students have any failures in the application of the fourth stage of PWA?

- Is there a difference between the female and male students in terms of the failure in the application of the fourth stage of PWA?

- Is there a difference between the successful and unsuccessful students in terms of the failure in the application of the fourth stage of PWA?

6. Do the students have any failures in the application of the fifth stage of PWA?

- Is there a difference between the female and male students in terms of the failure in the application of the fifth stage of PWA?

- Is there a difference between the successful and unsuccessful students in terms of the failure in the application of the fifth stage of PWA?

7. In which stage/stages of PWA do the students have difficulties most?

- In which stage/stages of PWA do the female and male students have difficulties most?

- In which stage/stages of PWA do the successful and unsuccessful students have difficulties most?

\subsection{The Process Writing Approach}

PWA suggests a systematic procedure for writing. It presents a clear to-do list for each step of writing because it views writing as a combination of separate language functions or areas. Flower and Hayes (1981) note that PWA depends on four points: a) writing includes distinctive thinking process, b) these processes are connected to each other, c) composing is a goal-directed thinking process that is accomplished by the writer's network of goals, d) this process contains producing sub-goals and revising main goals.

PWA refers to a broad range of strategies that include pre-writing activities such as defining the audience, using a variety of resources, planning the writing, as well as drafting and revising (Goldstein \& Carr, 1996, p. 2). It is a common fact that writing is a recursive process in which students plan what to write, write down their ideas and review what they have written. In PWA, students have a chance to accomplish their writing process along with suitable feedback both from their instructors and peers. In this way, they can turn their first drafts that might be unorganized and that might have several grammatical errors into final drafts that are better organized and that have fewer grammatical errors.

In PWA, students are planners, writers, feedback providers and editors (Widodo, 2008, p. 103). First of all, they think and organize their writing before they begin to jot down it. Secondly, they check and assess their own and friend's drafts after writing their drafts. They explain their ideas about the draft and 
suggest changing something or correcting errors in it. Therefore, students are required to think critically and objectively as well as to reflect on what they have learned during the class. As a result, PWA encourages students to assume responsibility for their writing development.

Placing responsibility on students for their learning is not one and only benefit of PWA. There are other advantages, some of which are summarized as follows:

- It heartens learners to feel free to transmit their own thoughts or emotions in written messages by supplying them with time and opportunity to rethink and revise their text, and it makes them seek help from outside resources like the instructor at each stage.

- It focuses the process which writers go through in forming texts.

- It brightens collaborative group work among learners as a way of enlarging motivation and having positive attitudes towards writing.

- It encourages the development of skilled language use and a series of attractive classroom techniques.

- It gets learners to transfers comments or responses (Onozawa, 2010, p. 156-157).

Many PWA researchers have agreed that there are many stages which writers go through in the writing process but there is no consensus on the names and number of these stages. Montague (1995) claims that the process-oriented approach contains stages of the writing process just as pre-writing, writing, and re-writing (p. 15). On the other hand, Tompkins (1990) announces five stages for introducing the writing process including prewriting, drafting, revising, editing, and sharing (p. 72). Johnson (2008) also cites the five-step writing process, but he calls the last step as "publishing" instead of sharing (p. 179). There are also some specialists suggesting four stages for PWA. For example; according to Brown (2001) the stages are prewriting, drafting, and revising, and editing (p. 337). Similarly, Seow (2002) uses the same stages and names except for the first one, which is called planning (p. 315). Harmer (2004) also suggests four stages but they are a bit different, which are planning, drafting, editing and final version (p. 5). Finally, the number of stages can be expanded. Coffin et. al (2003) explain that the writing process includes eight different stages, which are pre-writing, planning, drafting, reflecting, peer or tutor reviewing, revising, editing and proofreading (p. 33).

When the details of these different ideas about the stages of PWA are examined, it is seen that the stages are the same, but the specialists prefer different names for them. It is obvious that PWA is mainly composed of five stages which are planning/pre-writing, drafting/writing, revising, editing and publishing/proofreading/sharing. For the purpose of this paper, it is determined that PWA is a set of stages such as pre-writing, drafting, revising, editing, and proofreading.

The first stage, pre-writing, prepares students for writing by making them decide what, how and why to write. The purpose of this stage is to enable student-writers to explore certain topics in an unstructured and non-threatening way before working on formal essays (Widodo, 2008, p. 103). It is a widespread idea that starting to write is a difficult task. Many students complain about not knowing what to write or how to start their sentences. Thus, this stage makes students think, find and plan what to write in a systematic way. It is likely that students move away from having to face a blank page toward generating tentative ideas and gathering information for writing at this stage.

Oshima and Hogue (2006) identify the main jobs of students at the first stage as (1) choosing a topic that interests the students, (2) narrowing the chosen topic that fits a writing task, and (3) collecting information and developing ideas. Students engage in different activities in order to achieve these jobs. While Seow (2002) offers group brainstorming, clustering, rapid free-writing, wh-questions (p. 316), Brown (2001) expands on the activities as brainstorming, listings, clustering, freewriting, reading a passage, skimming and scanning a passage (p. 348). For the purpose of this paper, students are to expected produce academic writing; the activities at this stage should serve this aim. Therefore; five 
activities- brainstorming, listing, asking journalist questions, researching and taking notes, and outlining- are used for the purpose of this study in this stage.

Kroll (2001) defines brainstorming as an activity “ . . in which all students in a group or class share their ideas about a certain topic" (p. 224). Brainstorming makes students focus on the topic within a limited time. They can force themselves to think about what to write. As for listing, it is an individual activity and it lets students write a lengthy list including main ideas and subcategories about a particular topic (Kroll, 2001, p. 224). Listing can make students be more conscious of their background knowledge about the topic. They can have a chance to list what they know about the topic. Asking journalist questions, which are also named as wh-questions, makes students think about the topic and understand their lack of information about the topic. Researching and taking notes is an indispensable part of academic writing. Outlining is a type of graphic organizer and gives students a visual aid for the organization. This activity lets students order the ideas in a logical order and eliminate unrelated ideas. Students concentrate on their new and old knowledge about the topic and order their ideas. Besides, they focus on topic sentences and supporting details of each paragraph.

Students proceed to the second stage, drafting, once they have completed all the tasks at the prewriting stage. It is the stage in which students concentrate on getting their ideas on paper. In this stage, students are made to develop their ideas into rough drafts without considering the grammatical accuracy first (Widodo, 2008, p. 104). Depending on the genre of writing (narrative, expository or argumentative), an introduction to the subject of writing may be a startling statement to arrest the reader's attention, a short summary of the rest of the writing, an apt quotation, a provocative question, a general statement, an analogy, a statement of purpose, and so on (Seow, 2002, p. 317). After the introduction, students write their ideas about the topic in a fluent way. In drafting, students are asked to write their essays in one session, and they are warned to think about only the ideas. Students form and express their ideas with the help of their outline. Fulwiler (1996) advises teachers and students not to expect drafts having no errors at early stages. Besides, students have opportunities to change their ideas while they revise it or they correct their mistakes while they edit it. Thus, students are to focus on only transmiting their knowledge and ideas effectively at this stage.

The third stage, revising, means looking at the organization, main points, supporting details for main ideas, examples, and connections between ideas (Alodwan \& Ibnian, 2014, p. 147). It can be said that revising is not correcting mistakes, but it is rethinking about the draft in terms of organization and content. Writers reexamine what has been written to view how effectively they have transmitted their meanings to readers (Widodo, 2008, p. 104). Tompkins (1990) describes the features of revising as “... meeting the needs of readers through adding, substituting, deleting, and rearranging material" (p. 83). Students are asked to criticize their writing in terms of unity, coherence, and cohesion. They add new ideas, or they delete some ideas in their draft as well as replacing some ideas with others.

Seow (2002) suggests that revising can be done by the teacher, by pairs and individually (p. 318). It is important that the more a piece of writing is revised, the more perfect it can be; for this reason, students are encouraged to revise their writing at different times and to get it revised by different peers as much as possible. Providing sample revision questions encourages students to focus on the content of writing and to think about enhancing coherence and organization of writing (Bae, 2011, p. 24). Sample revision questions such as "What part does not make sense?" or "What details can be added?" can help students comprehend what they must focus on while they are providing feedback on peers' writing and their own writing.

Editing, the fourth stage, is defined by Tompkins (1990) as "putting the piece of writing into its final form" (p. 88). It is the stage in which grammatical, lexical, spelling, punctuational and some other kinds of mistakes are corrected. Students should be away from their writing and read it correcting grammatical 
and mechanical errors. The goal of this activity is to produce well-written essays before students submit the work to the teacher (Widodo, 2008, p. 104).

Seow (2002) suggests that the last stage, proofreading, includes "....any classroom activity that teacher and students can do with the completed pieces of writing such as publishing, sharing, reading aloud, transforming texts for stage performances, or merely displaying texts on notice-boards" (p.319). This stage is a platform for recognizing students' work as significant and worthwhile. It can be used as a motivation for writing as well as to hedge against students finding excuses for not writing. At this stage, students must be made to have an idea that they are writing for a real aim. In this study, students present their writing as a final assignment. Seow (2002) claims that many word-processing programs are user-friendly enough for students to handle (p. 320). Students benefit from these programs for the last version of their writing. Thus, students are expected to prepare their writing as a final assignment to be presented for their lecturer in this study. They are asked to use word-processing programs and to organize their writing according to the rules presented in the class.

As dividing the writing process into many stages and naming each stage can led students to confound that the stages are linear, teachers should explain that the stages are interactive, organic and cyclical. If one of the stages is not completed in an appropriate and whole way, students cannot start the next stage. Besides, if students realize a failure in one stage, they should return back to the stage which causes this failure and fulfill all the requirements of each stage

\section{Method}

This study concentrates on identifying in which stage/stages of PWA students have difficulties most; therefore the participants were asked to produce an essay with the help of PWA. The products of the students were analyzed with the help of percentage in order to identify the failure of the students in the stages of PWA. Therefore, this study is a posttest experimental design. All studies involving the dimensions of academic writing were conducted using PWA in the study group. All experimental procedures in this study were implemented by the researcher (the lecturer of the course at the same time).

\subsection{Participants}

The participants of the study were the first-year students studying English Translation and Interpreting at Kirıkkale University, during the spring term of 2017-2018 Academic Year. Due to the fact that there was only one class of students registered in this department, the whole participants, the number of whom was 50, were included into the experimental group (as there is only one group, it is called a study group hereinafter). Hence, the convenience sampling method is selected due to the availability of the participants to take part into the research. Although the number of the participants included in this study is limited and may not be representative to reach a comprehensive generalization concluded from the collected data, it would be useful to take into consideration that the number of the participants is acceptable for quantitative research. Out of these participants, 30 students were male, and the remaining 20 were female.

\subsection{Instrument( $(s)$}

The students were required to write an academic essay about a specific topic at the end of the procedure in which PWA was theoretically and practically conducted. These essays are the instrument of this study to collect data. All essays were evaluated with the help of the checklist prepared by the 
researcher according to the steps of PWA. In this checklist, each step of the approach corresponds to to different points. The first stage is 25 points, in which brainstorming, listing, asking journalist questions, researching and taking notes and outlining are each 5 points. The second stage, drafting, is 10 points. Writing at least 3 drafts is 5 points and choosing one of them as a final one is 5 points. Revising is 30 points. Revising their own paper, having their own paper revised, unity, cohesion, coherence, and meaning are separately 5 points. As for the fourth stage, editing their own paper, having their own paper edited, spelling, punctuation, grammar are 5 points, which totally makes 25 points. The last stage has three criteria, which are legibility-3 points, tidiness-4 points and reference-3 points. Thus, it makes 10 points.

\subsection{Data collection and analysis}

The study group dealt with PWA both at the theoretical and applicational base. At first, the students were informed about the process of the class. They were explained that they would be taught the theoretical part and made a sample application during the class hour. Then, they would do their assignment for their final paper out of the classroom each week. The students who would not complete the assignment for that week would not be able to take any marks for that week's assessment; however, he/she would do that assignment to pass the next step of PWA.

The experimental procedure lasted six weeks. The students had four class hours for each week. In the first two weeks, they were given instructions about the first stage of PWA, which is named as prewriting. After the study group was taught the brainstorming, listing and asking journalist questions with the examples and applications, they were assigned to do brainstorming on their own out of the class in order to choose and limit their own topic, to do listing in order to present their knowledge about the topic and to be aware of their background. Lastly, they were asked to carry out the next step asking journalist questions in order to prepare themselves to search on the topic. In the following week, after the students' assignments were checked, they were conducted about the second step of the first stage, that's researching and outlining. They were assigned to search their topic from online resources and libraries and to take notes; then they were to prepare their outline. Then, the students were taught how to write their drafts and they were assigned to write their own drafts and to choose their final draft in the third week. Next, the students were instructed on how to revise their and their friends' papers in the fourth week. Until the following class, they were advised to revise their own and their friends' papers as much as possible. Afterward, they dealt with on how to edit the paper in the class hour. Again, they were to edit their own and friends' papers as much as possible outside the class. Finally, the study group dealt with the last stage, proofreading. The lecturer instructed them on how to write their paper with the help of computer programs and by using the rules of writing an academic essay. Also, they were informed about the assessment procedure of their paper. At the end of this process, the essays of the students were collected and assessed by the researcher with the help of the checklist. Briefly, the experimental procedure of this study lasted twenty-four class hours as well as the time in which the students did their assignments on their own out of the class.

In order to determine the success and failure in the application of the approach, the students' own academic success in the school was used as a criterion. Since the students getting 60 marks will pass the course in Kirıkkale University, the students who got 60 at the end of the evaluation procedure was accepted as successful. All students were assessed in terms of the whole essays. Secondly, the points that students took for each stage of PWA in the evaluation procedure were calculated separately. All of these data were analysed with the help of the percentage in order to identify the failure of the students. Finally, the percentages of each stage of the approach were compared with each other to identify the stage or stages in which students have difficulties most. 


\section{Results}

The findings of the study associated with the answers of the assigned research questions are presented in the tables below.

Table 1: Findings according to the application of PWA

\begin{tabular}{lcccc}
\hline & \multicolumn{2}{c}{ HAVING SUCCESS } & \multicolumn{2}{c}{ HAVING FAILURE } \\
& Number & Percentage & Number & Percentage \\
All Students & 38 & $76 \%$ & 12 & $24 \%$ \\
Male Students & 24 & $80 \%$ & 6 & $20 \%$ \\
Female Students & 14 & $70 \%$ & 6 & $30 \%$ \\
\hline
\end{tabular}

For the first research question, data were analyzed by calculating the percentage to determine whether the students have a failure in the application of PWA. The students who get 60 and over at Kurkkale University can pass that course. Therefore, getting lower than 60 in the assessment is accepted as a failure in this study. As it is seen in Table 1, 24\% of the students failed in using PWA in their academic writing. As this percentage is below 50, it can be concluded that a few students have a failure in the application of PWA. Furthermore, it is clear that there is a fairly significant difference (10\%) between the female and male students in terms of failure in the application of PWA. Accordingly, the female students can be accepted as having a bit more failure in the application of PWA than the male students.

Table 2: Findings according to the application of the first stage of PWA

\begin{tabular}{lcccc}
\hline & \multicolumn{2}{c}{ HAVING SUCCESS } & \multicolumn{2}{c}{ HAVING FAILURE } \\
& Number & Percentage & Number & Percentage \\
All Students & 38 & $76 \%$ & 12 & $24 \%$ \\
Male Students & 24 & $80 \%$ & 6 & $20 \%$ \\
Female Students & 14 & $70 \%$ & 6 & $30 \%$ \\
Successful Students & 32 & $84 \%$ & 6 & $16 \%$ \\
Unsuccessful Students & 6 & $50 \%$ & 6 & $50 \%$ \\
\hline
\end{tabular}

The share of the first stage is 25 points in the checklist. When this mark is re-calculated considering the succeed mark-60 of the university, it is found as 15 points. Therefore, getting lower than this threshold value in the assessment is accepted as a failure in this study. As it is seen in Table 2, 24\% of the students failed in the application of the first stage of PWA, which means a few students have a failure in the first stage. Besides, there is a fairly significant difference (10\%) between the female and male students in terms of failure in the application of the first stage of PWA. Accordingly, the female students can be accepted as having a bit more failure in the first stage as it is in the application of PWA. As for the successful and unsuccessful students, it is obvious that there is a rather significant difference (34\%) between them. Thus, it can be concluded that the unsuccessful students have more failure in the application of the first stage of PWA than the successful students. 
Table 3: Findings according to the application of the second stage of PWA

\begin{tabular}{lcccc}
\hline & HAVING SUCCESS & \multicolumn{2}{c}{ HAVING FAILURE } \\
& Number & Percentage & Number & Percentage \\
All Students & 34 & $68 \%$ & 16 & $32 \%$ \\
Male Students & 23 & $77 \%$ & 7 & $23 \%$ \\
Female Students & 11 & $55 \%$ & 9 & $45 \%$ \\
Successful Students & 31 & $82 \%$ & 7 & $18 \%$ \\
Unsuccessful Students & 3 & $25 \%$ & 9 & $75 \%$ \\
\hline
\end{tabular}

The second stage, 10 points in the checklist, is found as 6 when calculated according to the succeed mark. Table 3 shows that $16 \%$ of the students failed in the application of the second stage of PWA because getting lower than 6 points in the assessment is accepted as a failure in this study. This means a few students have a failure in the second stage. Besides, the female students can be accepted as having much more failure in the second stage because there is a rather significant difference $(22 \%)$ between the female and male students. As for the successful and unsuccessful students, it is obvious that the unsuccessful students have far more failure in the application of the second stage of PWA than the successful students. Since there is a pretty significant difference $(57 \%)$ between them.

Table 4: Findings according to the application of the third stage of PWA

\begin{tabular}{lcccc}
\hline & HAVING SUCCESS & \multicolumn{2}{c}{ HAVING FAILURE } \\
& Number & Percentage & Number & Percentage \\
All Students & 35 & $70 \%$ & 15 & $30 \%$ \\
Male Students & 23 & $77 \%$ & 7 & $23 \%$ \\
Female Students & 12 & $60 \%$ & 8 & $40 \%$ \\
Successful Students & 32 & $84 \%$ & 6 & $16 \%$ \\
Unsuccessful Students & 3 & $25 \%$ & 9 & $75 \%$ \\
\hline
\end{tabular}

Getting lower than 18 points is accepted as a failure as threshold value in the assessment of the third stage is 18. As it is seen in Table 4, nearly half of the students (30\%) have a failure in the application of the second stage of PWA. Furthermore, the female students can be accepted as having far more failure in the third stage because there is a quite significant difference (17\%) between the female and male students. However, it is seen that there is a pretty significant difference (59\%) between the successful and unsuccessful students. Thus, the unsuccessful students can be said to have far more failure in the application of the third stage of PWA than the successful students. 
Table 5. Findings according to the application of the fourth stage of PWA

\begin{tabular}{lcccc}
\hline & \multicolumn{2}{c}{ HAVING SUCCESS } & \multicolumn{2}{c}{ HAVING FAILURE } \\
& Number & Percentage & Number & Percentage \\
All Students & 40 & $80 \%$ & 10 & $\% 20$ \\
Male Students & 24 & $80 \%$ & 6 & $\% 20$ \\
Female Students & 16 & $80 \%$ & 4 & $\% 20$ \\
Successful Students & 36 & $95 \%$ & 2 & $\% 5$ \\
Unsuccessful Students & 4 & $33 \%$ & 8 & $\% 67$ \\
\hline
\end{tabular}

Threshold value of the fourth stage is 15 , thus getting lower than 15 points means a failure in the study. As it is seen in Table 5, 10\% of the students failed in the application of the fourth stage of PWA, which means only a few students have a failure in the fourth stage. Besides, there is no difference between the female and male students in terms of failure in the application of the fourth stage of PWA because their percentages are both $20 \%$. Accordingly, the male and female students can be accepted as having an equal failure in the fourth stage. On the contrary, it is obvious that there is a remarkably significant difference (62\%) between the successful and unsuccessful students. It can be understood that the unsuccessful students have much more failure in the application of the fourth stage of PWA than the successful ones.

Table 6. Findings according to the application of the fifth stage of PWA

\begin{tabular}{lcccc}
\hline & \multicolumn{2}{c}{ HAVING SUCCESS } & \multicolumn{2}{c}{ HAVING FAILURE } \\
& Number & Percentage & Number & Percentage \\
All Students & 46 & $92 \%$ & 4 & $8 \%$ \\
Male Students & 29 & $97 \%$ & 1 & $3 \%$ \\
Female Students & 17 & $85 \%$ & 3 & $15 \%$ \\
Successful Students & 37 & $97 \%$ & 1 & $3 \%$ \\
Unsuccessful Students & 9 & $75 \%$ & 3 & $25 \%$ \\
\hline
\end{tabular}

The share of the fifth stage is 10 points in the checklist. It is calculated as 6 according to the succeed mark. Therefore, getting lower than 6 points in the assessment means a failure in this study. It is found that only a few students (8\%) have failure in the application of the fifth stage of PWA, as seen in Table 6. Similarly, there is a bit significant difference (12\%) between the female and male students; therefore, the female students can be accepted as having fairly more failure in the fifth stage than the male students. As for the successful and unsuccessful students, it is obvious that there is a quite significant difference (22\%) between them. Thus, the unsuccessful students can be accepted as having a bit more failure in the application of the fifth stage of PWA than the successful students.

Table 7. Findings relating to the which stage that students have the most difficulty in

\begin{tabular}{lccccc}
\hline & 1. Stage & 2. Stage & 3. Stage & 4. Stage & 5. Stage \\
All Students & $24 \%$ & $32 \%$ & $30 \%$ & $20 \%$ & $8 \%$ \\
Male Students & $20 \%$ & $23 \%$ & $23 \%$ & $20 \%$ & $3 \%$ \\
Female Students & $30 \%$ & $45 \%$ & $40 \%$ & $20 \%$ & $15 \%$ \\
\hline
\end{tabular}




\begin{tabular}{lccccc}
\hline Successful Students & $16 \%$ & $18 \%$ & $16 \%$ & $5 \%$ & $3 \%$ \\
Unsuccessful Students & $50 \%$ & $75 \%$ & $75 \%$ & $67 \%$ & $25 \%$ \\
\hline
\end{tabular}

As for the last research question, it is obvious in Table 7 that the second stage is the stage that the students had the most difficulties. Thus, drafting is the stage in which the whole group, the female and male students, the successful and unsuccessful students face the most failure at different rate. Moreover, the male students and the unsuccessful students had difficulties at the same rate in the application of the third stage of PWA. As a consequence, it can be said that the most difficult stage of PWA is drafting. Furthermore, Revising is also as difficult as drafting for the male students and the unsuccessful students

\section{Discussion}

This study is different from previous ones which put forward that PWA improves students' development of writing on the grounds that it presents inner research in PWA. However, one of the conclusions drawn from this study agrees with the findings of those studies presenting the effectiveness of PWA (Bayat, 2014; Cheung \& Chan, 1994; Daze \& Ebibi, 2014; Goldstein \&Carr, 1996; Ho, 2006; Jacob \&Talshir, 1998; Mahon \& Yau, 1992; Nabhan, 2016; Olajide, 2013; Schanella, 1982). Similarly, this study concludes that majority of the students didn't have failure in the application of PWA, which means they had success in applying PWA. They produced successful academic essays with the help of this approach. One reason for this success is that the students did the preparation and had a plan for writing; therefore, they knew what and how to write. Another reason for this success is that students had a chance to review, check and evaluate their essays many times. Since this checking was carried out by students and their friends, the written essays contained fewer errors.

This study has concluded that the female students have more difficulties in the application of PWA than the male students. This is a surprising result when the studies that have concluded that females have better achievement in writing ability than males (Camarata \& Woodcock, 2006; Nowell \& Hedges, 1998; Pajares \& Valiante, 1999; Reilly, Neumann \& Andrews, 2019; Reynolds, Scheiber, Hajovsky, Schwartz \& Kaufman, 2015; Scheiber, Reynolds, Hajovsky \& Kaufman, 2015) are taken into consideration. It is thought that this controversial finding can result from the individual differences of the participants. Besides, this study does not refer to the whole writing ability as it investigates the application of PWA.

This study finds out that drafting is the most difficult stage of PWA. It is not surprising because drafting is the stage in which students produce their writing. Although they prepare themselves to generate in the pre-writing stage, students have difficulties in explaining their ideas with a whole sentence. Another reason for this difficulty can be that the students could not make enough preparation for academic writing in the pre-writing stage. In order to write academically, students should search for their topic best and reflect their knowledge and ideas based on this research. Murray (1972) claims that pre-writing usually takes about $85 \%$ of the writer's time while drafting takes as little as one percent of the writer's time and rewriting takes 14 percent of the time of the writer (p. 3). It is very surprising that the stages which take least time are found to be the most difficult ones in this study. However, $85 \%$ of the total time is very long for preparation. The writer who spent $85 \%$ of his/her time in pre-writing stage can be accepted as ready for generating. Thus, this claim of Murray can be a clue for this study that the students could not have made enough preparation for drafting because the students had only two weeks for pre-writing and one week for drafting. 


\section{Conclusions}

As it is obvious from the present study, PWA is a difficult and time-consuming approach in writing. Drafting and revising are problematic stages for students. Thus, teachers should be careful about these stages. They should warn students to make enough preparation before the production stage. Also, teachers should pay attention to the structure of paragraphs more in the class. It is likely that having separate lectures on the organization of paragraphs before the application of PWA will be useful for students. In this study, the study group was asked to write at least three drafts for one week. It may be a good idea to ask students to write more drafts in a longer time as two weeks. Also, searching is limited to one week. Adding one more week to this may get students to make enough preparation before starting to write. It is thought that some stages of PWA, especially the first and the second stages, require much more time. Furthermore, the difficulties encountered during the process of PWA should be examined in some other studies which can be performed in longer periods. As a result, this study presents that students can have successful writing via PWA although they have some difficulties in the production stage. Thus, it is suggested that this approach be used in writing classes considering the findings of this study.

\section{Ethics Committee Approval}

The author(s) confirm(s) that the study does not need ethics committee approval according to the research integrity rules in their country (Date of Confirmation: March 03, 2020).

\section{References}

Alodwan, T. A. A., \& Ibnian, S. S. K. (2014). The effect of using the process approach to writing on developing university students' essay writing skills in EFL. Review of Arts and Humanities, 3(2), 139-155. Retrieved on December 6, 2018 from http://rahnet.com/journals/rah/Vol_3_No_2_June_2014/11.pdf.

Bae, J. (2011). Teaching process writing for intermediate/advanced learners in South Kore (Unpublished MA Thesis). University of Wisconsin-River Falls, South Korea.

Bayat, N. (2014). The effect of PWA on writing success and anxiety. Educational Sciences: Theory \& Practice, 14(3), 1133-1141. Retrieved on December 6, 2018 from www.edam.com.tr/estp. DOI: 10.12738/estp.2014.3.1720.

Brown, H. D. (2001). Teaching by principles: An interactive approach to language pedagogy. (1 $\left.1^{\text {st }} \mathrm{ed}.\right)$. White Plains: Addison Wesley Longman.

Camarata, S., \& Woodcock, R. (2006). Sex differences in processing speed: Developmental effects in males and females. Intelligence, 34, 231-252. DOI: 10.1016/j.intell.2005.12.001.

Cheung, M., \& Chan, A. (1994). Teaching writing as a process. Hong Kong: Education Department.

Coffin, C., Curry, M. J., Goodman, S., Hewings, A., Lillis, T. M. \& Swan, J. (2003). Teaching academic writing: A toolkit for higher education. London: Routledge.

Daze, B. D. \& Ebibi, J. O. (2014). Effect of process approach to writing on senior secondary students' achievement in writing (Plateau Central Senatorial District). International Journal of Arts and Humanities Bahir Dar-Ethiopia, 3(4), 47-59, DOI: 10.4314/ijah.v3i4.4 
Flower, L., \& Hayes, J. R. (1981). A cognitive process theory of writing. College Composition and Communication, 32(4), 365-387.

Fulwiler, T. (1996). The college writer's reference. Upper Saddle River: Prentice Hall Print.

Goldstein, A. A., \& Carr, P. G. (1996). Can students benefit from process writing, NCES Report, 3(1), 96-845.

Harmer, J. (2004). How to teach writing. London: Pearson Education Limited.

Ho, B. (2006). Effectiveness of using the process approach to teach writing in six Hong Kong primary classrooms. Perspectives: Working Paper in English and Communication, 17(1). Retrieved on November 24, 2018 from http://citeseerx.ist.psu.edu/viewdoc/download?

Jacob, G., \& Talshir, P. (1998). Creative writing. English Teachers' Journal (Oct.), 64-65.

Johnson, A. P. (2008). Teaching reading and writing: A guidebook for tutoring and remediating students. New York: Rowman and Littlefield Education.

Kroll, Barbara. (2001). Considerations for teaching an ESL/EFL writing course. In M. Celce-Murcia (Ed.), Teaching English as a second or foreign language, (pp: 219-232). Boston: Heinle and Heinle.

Maccoby, E. E., \& Jacklin, C. N. (1974). The psychology of sex differences. Stanford, CA: Stanford University Press.

Mahon, T., \& Yau, R. (1992). Introducing a process approach in the teaching of writing in a lower primary classroom. ILEJ, 9, 23-29.

Montague, N. (1995). The process-oriented approach to teaching writing to second language learners. New York State Association for Bilingual Education Journal, 10, 13-24.

Murray, D. (1972). Teach writing as a process not product. The Leaflet, 71, 11-14.

Nabhan, S. (2016). The process approach to improve students' writing ability in English education department University of Pgri Ad1 Buana Surabaya, Journal Pengajaran Bahasa dan Sastra, 13, 116.

Nowell, A., \& Hedges, L. V. (1998). Trends in gender differences in academic achievement from 1960 to 1994: An analysis of differences in mean, variance, and extreme scores. Sex Roles, 39, 21-43. DOI: $10.1023 / \mathrm{A}: 1018873615316$.

Olajide, J. L. (2013). Effect of integrated approach on polytechnic students' achievement in essay writing. Journal of Emerging Trends in Educational Research and Policy Studies (JETERAPS), 4(6), 917-924.

Onozawa, C. (2010). A study of the Process Writing Approach: A suggestion for an eclectic writing approach. Research Note, pp. 153-163.

Oshima, A., \& Hogue, A. (2006). Writing academic English. New York: Pearson Education.

Pajares, F., \& Valiante, G. (1999). Grade Level and Gender Differences in the Writing Self-Beliefs of Middle School Students. Contemporary Educational Psychology, 24(4), 390-405.

Raimes, A. (1983). Techniques in teaching writing. Oxford: Oxford University Press.

Reilly, D., Neumann, D. L., \& Andrews, G. (2019) Gender Differences in Reading and Writing Achievement: Evidence From the National Assessment of Educational Progress (NAEP). American Psychologist 74(4), 445-458. DOI: 10.1037/amp0000356. 
Reynolds, M. R., Scheiber, C., Hajovsky, D. B., Schwartz, B. \& Kaufman, A. S. (2015). Gender differences in academic achievement: Is writing an exception to the gender similarities hypothesis? The Journal of Genetic Psychology, 176(4). DOI: 10.1080/00221325.2015.1036833.

Scannella, A. M. (1982). A writing-as-process model as a means for improving compositions and attitudes toward composition in the high school. Doctoral dissertation. Available from ProQuest Dissertations and Theses database. (UMI No. 8301605).

Scheiber, C., Reynolds, M. R., Hajovsky, D. B., \& Kaufman, A. S. (2015). Gender differences in achievement in a large, nationally representative sample of children and adolescents. Psychology in the Schools, 52, 335-348. DOI: 10.1002/pits.21827.

Seow, A. (2002). The writing process and process writing. In J. C. Richards \& W. A. Renandya (eds.). Methodology in language teaching: An anthology of current practice, (pp. 315-320). Cambridge: Cambridge University Press.

Tompkins, G. E. (1990). Teaching writing: Balancing process and product. Columbus: Merrill Print.

Widodo, H. P. (2008). Process-based academic essay writing instruction an EFL context. Bahasa Dan Seni, 36(1), 101-111

\section{Öğrencilerin süreç odaklı yazma yaklaşımında karşılaştıkları zorluklar}

\section{$\ddot{O} z$}

Süreç Odaklı Yazma Yaklaşımı dil öğretiminde öğrencilerin yazma becerisini geliştirdiği kanıtlanan ve oldukça bilinen bir yaklaşımdır. Ancak öğrencilerin bu yaklaşımın uygulanması sırasında zorluk yaşayıp yaşamadıkları araştırılması gereken bir konudur. Bu nedenle, bu çalışmanın amacı öğrencilerin bu yaklaşımı uygularken yaklaşımın hangi aşamasında en fazla zorluk yaşadıklarını belirlemektir. Sontest-Deneysel desenli bu çalışma 2017-2018 Akademik Yılında Kırıkkale Üniversitesi İngilizce Mütercim Tercimanlık Anabilimdalında öğrenim gören 50 birinci sınıf öğrencisi ile gerçekleştirilmiştir. Söz konusu yaklaşımın kuramsal ve uygulamalı işlenişini içeren süreç sonunda öğrencilerin bir makale yazmaları gerekmektedir. Araştırma verileri öğrenciler tarafından yazılmış olan bilimsel makaleden elde edilmiştir. Öğrencilerin makaleleri araştırmacı tarafindan yaklaşımın aşamaları göz önüne alınarak hazırlanmış olan bir kontrol listesi ile değerlendirilmiştir. Elde edilen veriler yüzde hesaplaması yardımıyla analiz edilmiştir. Analiz sonucunda öğrencilerin yazma dersinde yaklaşımı uygulamada başarılı oldukları görülmüştür. Ayrıca, öğrencilerin en fazla zorluğu yaklaşımın ikinci aşaması olan taslak oluşturma aşamasında yaşadıkları tespit edilmiştir. Bu nedenle öğretmenler üretim aşamasından önce öğrencileri yeterince hazırlık yapmaları konusunda uyarmalıdır. Ayrıca, yaklaşımın uygulanmasından önce paragraf düzeni ve öğeleri konusunda öğrencilerin bilgilendirilmesinin onlar için yararlı olacağı düşünülmektedir. 


\section{AUTHOR BIODATA}

Nejla Gezmiş worked as a teacher of English at elementary, secondary and high schools for about 11 years after she had graduated from ELT Department in Hacettepe University in 2002. Meanwhile, she completed BA and $\mathrm{PhD}$ degrees at Department of Foreign Language Teaching in Ankara University. She has been working as an assistant professor at the Division of Translation and Interpretation in English in Kirkkale University since 2013. She has been lecturing several classes such as Reading, Writing, Media Translation, Text Translation, Medical Translation and Turkish for Translators. Her research interests lie in foreign language teaching, developing teaching materials and teaching translation. 